\title{
A CLINICAL STUDY ON INCIDENCE, PATHOLOGICAL PATTERN AND MANAGEMENT OF GASTRIC CARCINOMA IN RURAL SETUP (ADICHUNCHANAGIRI INSTITUTE OF MEDICAL SCIENCES), MANDYA
}

\author{
Abinash Hazarika1, Partha Pratim Bora², K. Santhosh Kumar ${ }^{3}$ \\ 1 Professor, Department of General Surgery, Adichunchangiri Institute of Medical Sciences, Mandya. \\ 2Post Graduate, Department of General Surgery, Adichunchangiri Institute of Medical Sciences, Mandya. \\ ${ }^{3}$ Post Graduate, Department of General Surgery, Adichunchangiri Institute of Medical Sciences, Mandya.
}

\begin{abstract}
BACKGROUND

Stomach cancer or gastric cancer is when cancer develops from the lining of stomach. Early symptoms may include heartburn, upper abdominal pain, nausea and loss of appetite. Later symptoms may include weight loss, yellow skin, vomiting, difficulty swallowing and blood in the stool among others. The cancer may spread from the stomach to other parts of the body, particularly the liver, lungs, bones, lining of the abdomen and lymph nodes. The most common cause is infection by the bacteria Helicobacter pylori, which accounts for more than $60 \%$ of cases. About $10 \%$ of cases run in families and between $1 \%$ and $3 \%$ of cases are due to genetic syndromes inherited from a person's parents such as hereditary diffuse gastric cancer.
\end{abstract}

\section{AIMS AND OBJECTIVES}

1) To study the prevalence of carcinoma stomach as occurring in Adichunchanagiri Institute of Medical Sciences and Research Centre, Mandya. 2) To study the clinical presentation including the anatomic site of occurrence and histological type. 3) To study the association of risk factors. 4) To study the surgical modalities of treatment.

\section{METHODS}

The tissue for diagnosis was obtained by endoscopy or following surgical resection. Patients presenting to Adichunchanagiri Hospital, Mandya, during the study period and those found eligible were included in the study.

\section{Sample Size \\ Minimum of 50 cases meeting criteria of the present study.}

\section{RESULTS}

Gastric carcinoma is more common in males with $56 \%$ of the cases being males in this study. The prevalence is more among the low socio-economic group, which is $80 \%$ of the population. Smoked foods is a risk factor in 15 (30\%) of the patients and 40 (80\%) in high spicy diet in everyday food. Tobacco smoking (44\%), alcohol consumption (44\%) are also risk factors. Blood Group A is associated with gastric cancer, 23 (46\%) patients. Anorexia was the most common symptoms reported in 42 (84\%) of the patients. Anaemia was the most common sign in $35(70 \%)$ of the cases. The most common macroscopic subtype was Bor rmann type II with $24(48 \%)$. Majority of the cases were well differentiated adenocarcinoma, which is $30(60 \%)$ cases of which females had higher percentage of poorly differentiated tumours, i.e. 6 (27.2\%) cases.

\section{CONCLUSION}

This study was undertaken to study the prevalence of gastric cancer as occurring in Adichunchanagiri Hospital, Mandya, which is a rural hospital with a large input of cases from Mandya and its surrounding districts. In this study, gastric cancer was more prevalent in males. Majority of the patients belonged to the lower socioeconomic strata and had association of risk factor. Blood Group A was the prevalent blood group. The disease was more prevalent in patients above age of 45 with the oldest being 78. Majority presented in the advanced stage of the disease, although there were few cases which presented in the early gastric carcinoma stage. The pylorus remained the most common site of affliction in contrast to western countries, which have showed a consistent shift towards proximal tumours. The major percentage of the tumours was well differentiated. The finding of this study are comparable to other similar studies in India and proximal tumours continue to be the major subtype in this part of the world and association of risk factor increase the likelihood of an individual developing gastric cancer.

\section{KEYWORDS}

Gastric carcinoma, H. pylori, Adenocarcinoma.

HOW TO CITE THIS ARTICLE: Hazarika A, Bora PP, Kumar KS. A clinical study on incidence, pathological pattern and management of gastric carcinoma in rural setup (Adichunchanagiri Institute of Medical Sciences), Mandya. J. Evolution Med. Dent. Sci. 2016; 5(36): 2114-2122. DOI: $10.14260 /$ jemds/2016/496

Financial or Other, Competing Interest: None.

Submission 23-01-2016, Peer Review 20-02-2016,

Acceptance 26-02-2016, Published 04-05-2016.

Corresponding Author:

Dr. Abinash Hazarika,

Professor's Quarters, 'B' Block-22,

AIMS, B. G. Nagara,

Nagamangala-571448, Karnataka.

E-mail: hazarikadrabinash@gmail.com

DOI: $10.14260 /$ jemds $/ 2016 / 496$

\section{INTRODUCTION}

Early gastric cancer is defined as adenocarcinoma limited to the mucosa and submucosa of the stomach, regardless of lymph node status. The entity is common in the orient, where gastric cancer is the common cause of cancer death and where aggressive surveillance programs have therefore been established. Approximately, $10 \%$ of patients with early gastric will have lymph node metastases. There are several types and subtypes of early gastric cancer. 
Approximately, $70 \%$ of early gastric cancers are well differentiated and $+30 \%$ are poorly differentiated. The overall cure rate with adequate gastric resection and lymphadenectomy is $95 \%$. In some Japanese centres, $50 \%$ of the gastric cancers treated are early gastric cancer. In the United States, less than $20 \%$ of resected gastric adenocarcinomas are early gastric cancer. Small intramucosal lesions can be treated with EMR.

Stomach cancer or gastric cancer is when cancer develops from the lining of stomach.(1) Early symptoms may include heartburn, upper abdominal pain, nausea and loss of appetite. Later symptoms may include weight loss, yellow skin, vomiting, difficulty swallowing and blood in the stool among others.(2) The cancer may spread from the stomach to other parts of the body, particularly the liver, lungs, bones, lining of the abdomen and lymph nodes.(3)

The most common cause is infection by the bacteria Helicobacter pylori, which accounts for more than $60 \%$ of cases.(4),(5) Certain types of H. pylori have greater risks than others. Other common causes include smoking and eating pickled vegetables. About $10 \%$ of cases run in families and between $1 \%$ and $3 \%$ of cases are due to genetic syndromes inherited from a person's parents such as hereditary diffuse gastric cancer. Most cases of stomach cancers are gastric carcinomas. This can be divided into a no. of subtypes. Lymphomas and mesenchymal tumours may also develop within the stomach.

Most of the time, stomach cancer develops through a no. of stages over a no. of years. (5) Diagnosis is usually by biopsy done during endoscopy. This is then followed by medical imaging to determine if the disease has spread to other parts of the body.(2) At least Japan and South Korea, two countries that have high rates of disease, screen for stomach cancer.(5)

A Mediterranean diet lowers the risk of cancer as does the stopping of smoking.

There is tentative evidence that treating $\mathrm{H}$. pylori decreases the future risk.(5),(6) If cancer is treated early, many cases can be cured.(5) Treatments may include some combination of surgery, chemotherapy, radiation therapy and targeted therapy.(2) If treated late palliative care may be advised.(5) Outcomes are often poor with a less than 10\% 5year survival rate globally. This is largely because most people with the condition present with advanced disease.(7) In the United States 5-year survival is $28 \%$.(8) while in South Korea it is over $65 \%$ partly due to screening efforts. ${ }^{(5)}$

\section{AIMS AND OBJECTIVES OF THE STUDY}

1. To study the prevalence of carcinoma stomach as occurring in Adichunchanagiri Institute of Medical Sciences and Research Centre, Mandya.

2. To study the clinical presentation including the anatomic site of occurrence and histological type.

3. To study the association of risk factors.

4. To study the surgical modalities of treatment.

ANNUAL PREVALENCE: GRAPH 1

Gastric Carcinoma is a Common Cancer with Almost Evenly Distributed Annual Prevalence.

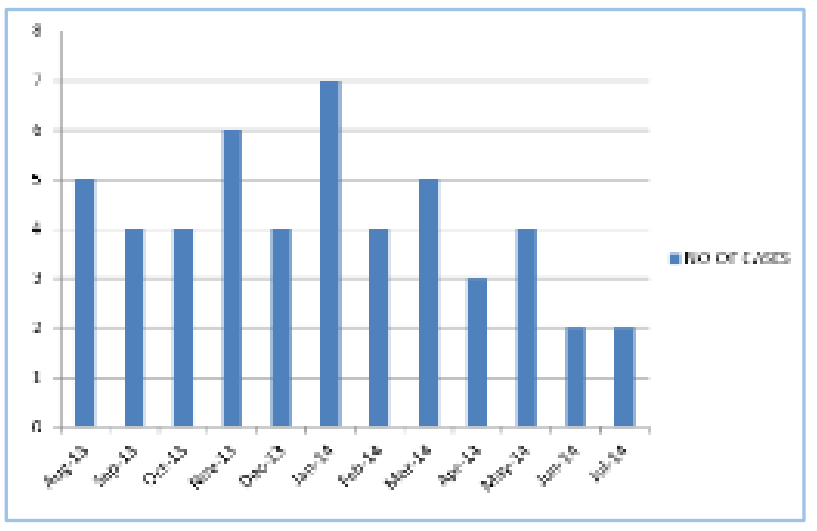

SEX PREVALENCE: TABLE 7; GRAPH 2

Sex Distribution among Carcinoma of Stomach Patients Gastric cancer is more common in males with $56 \%$ of cases being males in this study.

\begin{tabular}{|c|c|c|}
\hline Sex & $\begin{array}{c}\text { Present Study } \\
\text { Cases }\end{array}$ & $\mathbf{\%}$ \\
\hline Males & 28 & 56 \\
\hline Females & 22 & 44 \\
\hline
\end{tabular}

\section{\% OF INCIDENCE-SEX DISTRIBUTION}

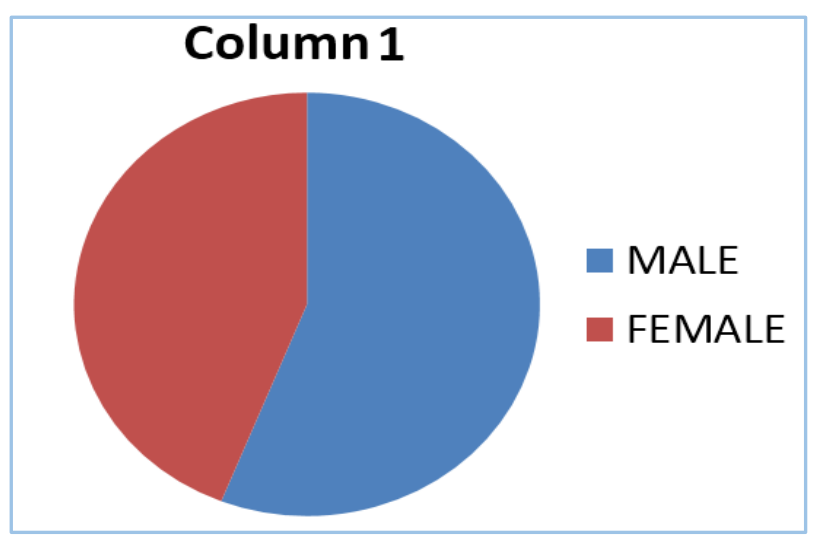

AGE PREVALENCE: TABLE 8; GRAPH 3

Age Distribution among Carcinoma of Stomach Patients

\begin{tabular}{|c|c|c|c|c|}
\hline & Present Study & & & \\
\hline Age & Total & $\mathbf{\%}$ & M & F \\
\hline$<30$ & 1 & 2 & 1 & 0 \\
\hline $30-39$ & 7 & 14 & 1 & 6 \\
\hline $40-49$ & 9 & 18 & 2 & 7 \\
\hline $50-59$ & 15 & 30 & 11 & 4 \\
\hline $60-69$ & 12 & 24 & 8 & 4 \\
\hline $70-79$ & 6 & 12 & 5 & 1 \\
\hline $80+$ & 0 & 0 & 0 & 0 \\
\hline
\end{tabular}

Age Distribution among Carcinoma of Stomach Patients

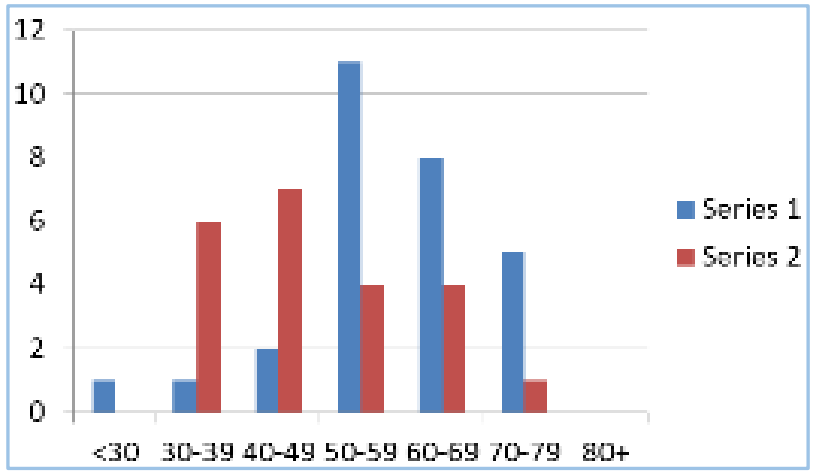




\section{SOCIOECONOMIC STATUS: TABLE 9; GRAPH 4}

Income group among carcinoma of stomach patients, the prevalence among the high socioeconomic group could not be studied, as none of the patients belonged to this strata.

\begin{tabular}{|c|c|c|}
\hline & Present Study & \\
\hline Income Group & Cases & \% \\
\hline Low & 40 & 80 \\
\hline Middle & 10 & 20 \\
\hline High & 0 & 0 \\
\hline
\end{tabular}

\section{\% OF INCIDENCE - SOCIOECONOMIC DISTRIBUTION}

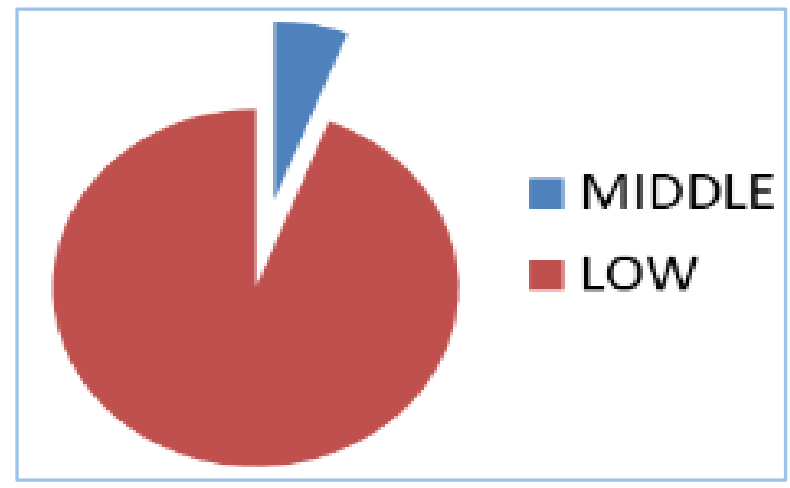

\section{RISK FACTORS: TABLE 10; GRAPH 5.0, 5.1}

There are strong suggestions of the influence of environmental factors on gastric cancer. The most common risk factors associated were spicy food and mixed diet followed by tobacco and alcohol use. In this study, 45 (90\%) patients consumed mixed diet and rest were vegetarians. The non-vegetarians took meat or fish approx. thrice every week. All patients in the study group frequently and regularly consumed green leafy vegetables. Fruit consumption was frequent only in 40 (80\%) of all the cases. Smoked foods though common risk factors in many countries was consumed only by 15 (30\%) of the patients and even in these patients the intake was not frequent. Majority of patients $40(80 \%)$ reported to the use of highly spicy diet as everyday food. Tobacco smoking in the form of cigarette and beedi smoking was seen in 22 (44\%) patients all being males.

Five females and 3 males reported to frequent use of betel nut, which has been shown to be a risk factor in the development of gastric cancer.

Alcohol consumption was seen in $22(44 \%)$ of the patients, all males who consumed it regularly and for a period of more than 10 years.

\begin{tabular}{|c|c|c|c|c|c|c|}
\hline & Total & & Males & & Females & \\
\hline & Cases & $\%$ & Cases & $\%$ & Cases & $\%$ \\
\hline Mixed Diet & 45 & 90 & 26 & 92.8 & 19 & 86.3 \\
\hline Veg Diet & 5 & 10 & 2 & 7.2 & 3 & 13.7 \\
\hline $\begin{array}{c}\text { Green } \\
\text { Leafy }\end{array}$ & 40 & 80 & 25 & 89.2 & 15 & 68.1 \\
\hline Fruits & 40 & 80 & 24 & 85.7 & 16 & 72.7 \\
\hline $\begin{array}{c}\text { High Salt } \\
\text { Intake }\end{array}$ & 32 & 64 & 20 & 71.4 & 12 & 54.5 \\
\hline $\begin{array}{c}\text { Smoked } \\
\text { Food }\end{array}$ & 15 & 30 & 10 & 35.7 & 5 & 22.7 \\
\hline Spicy & 40 & 80 & 25 & 89.2 & 15 & 68.1 \\
\hline Smoking & 22 & 44 & 22 & 78.5 & 0 & 0 \\
\hline Alcoholism & 22 & 44 & 22 & 78.5 & 0 & 0 \\
\hline Betel Nuts & 8 & 16 & 3 & 10.7 & 5 & 22.7 \\
\hline \multicolumn{7}{|c|}{ Table 10: Comparison of risk factors between } \\
\hline
\end{tabular}

Comparison of Diet in Male and Female Patients

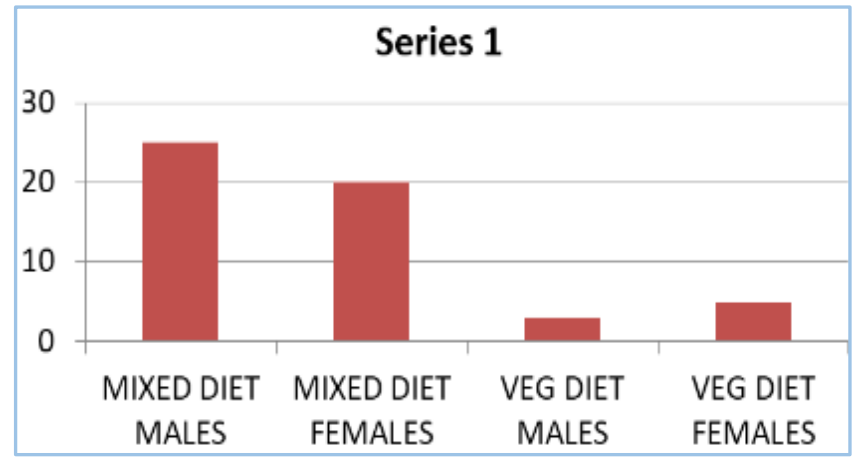

BLOOD GROUP: TABLE 11; GRAPH 6

Blood Group Distribution in Carcinoma Stomach Patients

\begin{tabular}{|c|c|c|c|c|}
\hline Study & $\begin{array}{c}\text { Blood } \\
\text { Group }\end{array}$ & & & \\
\hline & A & B & O & Ab \\
\hline $\begin{array}{c}\text { Present } \\
\text { Study }\end{array}$ & $23(46 \%)$ & $\begin{array}{c}9 \\
(18 \%)\end{array}$ & $\begin{array}{c}12 \\
(24 \%)\end{array}$ & $\begin{array}{c}6 \\
(12 \%)\end{array}$ \\
\hline
\end{tabular}

\section{\% OF INCIDENCE WITH DIFFERENT BLOOD GROUPS}

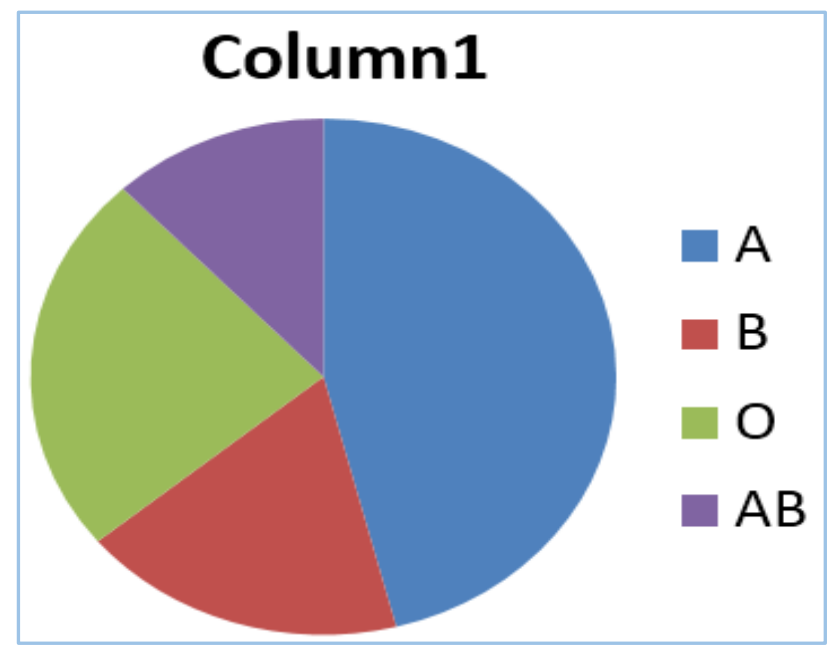

\section{SYMPTOMS: TABLE 12, GRAPH 7}

Anorexia was the most common symptoms in patients and was reported in $42(84 \%)$ of the patients. The next most common symptom was nausea and vomiting reflecting the high prevalence of distal tumours; $36(72 \%)$ reported weight $>10 \%$ of body weight. Proximal tumours involving the gastroesophageal junction had dysphagia as the predominant symptoms. Only 1 patient in this study presented with jaundice and none of the patients had supraclavicular lymphadenopathy at presentation. One patient presented with the features of peritonitis and was found to have a growth in the body of stomach, which had perforated.

Early satiety was reported in 25 (50\%) of the patients, which is characteristic of tumours involving the stomach wall diffusely. Symptoms analysis among the 2 sexes revealed that nausea, vomiting and weight loss were the most common symptoms followed by pain abdomen in females. The most common symptoms in males were anorexia, abdominal pain followed by nausea and vomiting. 


\begin{tabular}{|c|c|c|c|c|c|c|}
\hline Symptoms & $\begin{array}{c}\text { Present } \\
\text { Study }\end{array}$ & Males & $\mathbf{( 2 8 )}$ & Females & $\mathbf{( 2 2 )}$ \\
\hline & Cases & $\mathbf{\%}$ & Cases & $\mathbf{\%}$ & Cases & $\%$ \\
\hline $\begin{array}{c}\text { Abdominal } \\
\text { Pain }\end{array}$ & 40 & 80 & 23 & 82.1 & 17 & 77.2 \\
\hline $\begin{array}{c}\text { Nausea, } \\
\text { Vomiting }\end{array}$ & 33 & 66 & 18 & 64.2 & 15 & 68.1 \\
\hline Weight Loss & 36 & 72 & 20 & 71.4 & 16 & 72.7 \\
\hline Anorexia & 42 & 84 & 22 & 78.5 & 20 & 90.9 \\
\hline Early Satiety & 25 & 50 & 15 & 53.5 & 10 & 45.4 \\
\hline Jaundice & 1 & 2 & 1 & 3.5 & 0 & 0 \\
\hline Dysphagia & 5 & 10 & 2 & 7.1 & 3 & 10.7 \\
\hline Melena & 10 & 20 & 5 & 17.8 & 5 & 17.8 \\
\hline Table 12: Symptom Analysis in Patients of Carcinoma Stomach \\
\hline
\end{tabular}

\section{ANALYSIS OF SYMPTOMS IN GASTRIC CANCER PATIENTS}

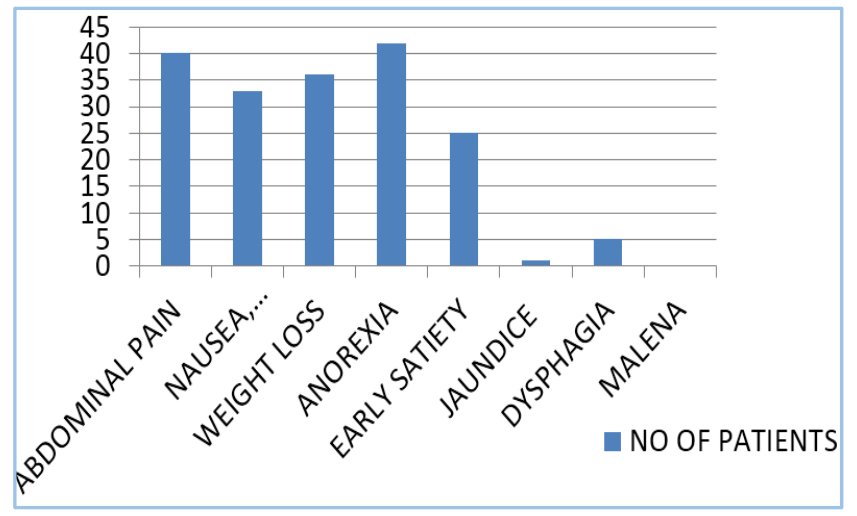

\section{SIGNS: TABLE 13, GRAPH 8}

Overall, anaemia was most common sign in 35 (70\%) of cases followed by dehydration and ascites.

Visible gastric peristalsis, the characteristic sign of gastric cancer was seen only in 7 (14\%) of the cases. Gastric cancer presented as mass abdomen in 17 (34\%) cases.

In females, anaemia and ascites were most common symptoms. None of the females in this study had visible gastric peristalsis, which was seen in 7 (25\%) of males.

Presentation with mass abdomen was commoner in females $10(45.4 \%)$ than in males 7 (25\%). Ascites at presentation suggesting the advanced stage of disease was more common in females compared to males.

\begin{tabular}{|c|c|c|c|c|c|c|}
\hline Signs & $\begin{array}{c}\text { Total } \\
\text { Cases }\end{array}$ & $\%$ & Males & & Females & \\
\hline & & & Cases & $\%$ & Cases & $\%$ \\
\hline Anaemia & 35 & 70 & 21 & 75 & 14 & 63.6 \\
\hline Icterus & 1 & 2 & 1 & 3.5 & 0 & 0 \\
\hline Dehydration & 30 & 60 & 18 & 64.2 & 12 & 54.5 \\
\hline Ascites & 28 & 56 & 17 & 60.7 & 11 & 50 \\
\hline VGP & 7 & 14 & 7 & 25 & 0 & 0 \\
\hline $\begin{array}{c}\text { Mass } \\
\text { Abdomen }\end{array}$ & 17 & 34 & 7 & 25 & 10 & 45.4 \\
\hline Table 13: Analysis of Signs in Gastric Cancer Patients \\
\hline
\end{tabular}

\section{ANALYSIS OF SIGNS IN BOTH THE SEXES}

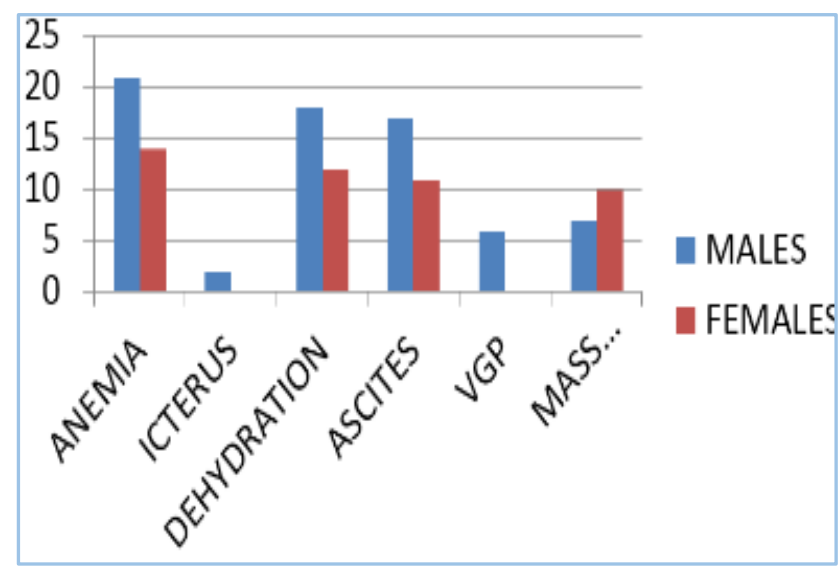

\section{SUBSITES: TABLE 14: GRAPH 9}

The antrum was the most common site of affliction accounting for $76 \%$ of all subsites. This was also similar in both the sexes with 20 males and 18 females. Oesophagogastric tumours accounted for $18 \%$ of the cases and were similar in both the sexes. None of the females in this study had cancer of the body and proximal stomach.

\begin{tabular}{|c|c|c|c|c|c|c|}
\hline Subsites & Total & & Males & & Females & \\
\hline & Cases & $\mathbf{\%}$ & Cases & $\mathbf{\%}$ & Cases & $\%$ \\
\hline OG Junction & 9 & 18 & 5 & 17.8 & 4 & 18.1 \\
\hline $\begin{array}{c}\text { Proximal } \\
\text { Stomach }\end{array}$ & 1 & 2 & 1 & 3.5 & 0 & 0 \\
\hline Body & 2 & 4 & 2 & 7.1 & 0 & 0 \\
\hline Antrum & 38 & 76 & 20 & 71.4 & 18 & 81.8 \\
\hline \multicolumn{7}{|c|}{ Table 14: Subsite Specific Trend in Carcinoma Stomach } \\
\hline
\end{tabular}

\section{SUBSITE TRENDS IN BOTH SEXES}

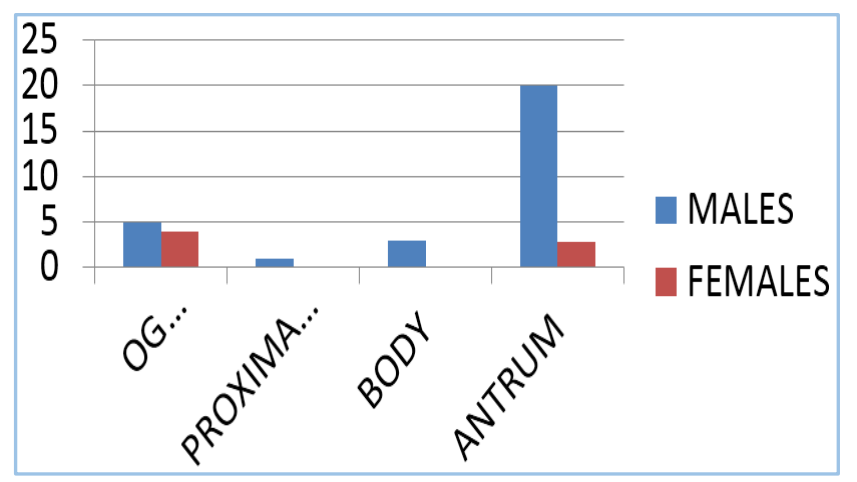

\section{MACROSCOPY: TABLE 15}

The predominant macroscopic subtype was Bormann type 2 with $48 \%$ followed by types III and IV. In males the predominant type was Bormann type II whereas in females it was type IV. Females had a higher\% of locally advanced lesions. There was no Bormann type I lesion in females in this study.

\begin{tabular}{|c|c|c|c|c|c|c|}
\hline Bormann & Total & & Males & & Females & \\
\hline Type & Cases & \% & Cases & \% & Cases & \% \\
\hline 1 & 2 & 4 & 2 & 7.1 & 0 & 0 \\
\hline 2 & 24 & 48 & 16 & 57.1 & 8 & 36.3 \\
\hline 3 & 10 & 20 & 5 & 17.8 & 5 & 22.7 \\
\hline 4 & 14 & 28 & 5 & 17.8 & 9 & 40.9 \\
\hline \multicolumn{7}{|c|}{ Table 15: Comparison of the } \\
\hline
\end{tabular}




\section{ANALYSIS OF BORMANN'S TYPE IN BOTH SEXES}

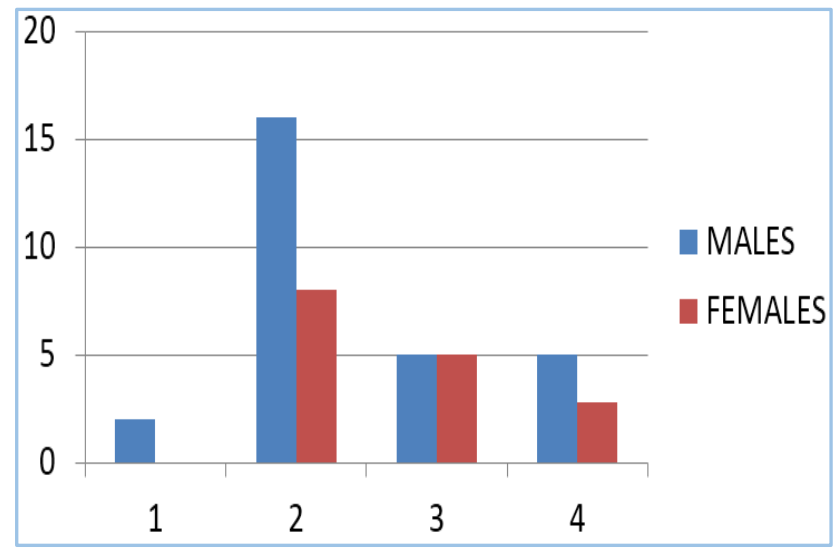

SITE AND SYMPTOMS: TABLE 16; GRAPH 10

Antral lesions presented predominantly with nausea or vomiting, weight loss, anorexia and pain abdomen; $50 \%$ of the antral growth patients also reported early satiety. Oesophagogastric tumour had dysphagia as the predominant symptom along with weight loss and anorexia reflecting the aggressive nature of such tumours.

Similarly, these entire lesions also had dysphagia as symptom. Melena was more common in lesion of the body followed by the antrum.

\begin{tabular}{|c|c|c|c|c|c|c|c|c|c|}
\hline \multirow{2}{*}{ Symptoms } & \multirow{2}{*}{ Total Cases } & \multicolumn{9}{|c|}{ Site of Tumour } \\
\cline { 3 - 10 } & & \multicolumn{2}{|c|}{ Antrum (38) } & \multicolumn{2}{c|}{ Proximal Stomach } & \multicolumn{2}{c|}{ Body } & \multicolumn{2}{c|}{ OG Junction } \\
\cline { 3 - 10 } & & Case & $\mathbf{\%}$ & Case & $\mathbf{\%}$ & Case & \% & Case & \% \\
\hline Abdominal pain & 40 & 32 & 84.2 & 1 & 100 & 1 & 50 & 6 & 66.6 \\
\hline Nausea/vomiting & 33 & 30 & 78.9 & 0 & 0 & 0 & 0 & 3 & 33.3 \\
\hline Weight loss & 36 & 31 & 81.5 & 0 & 0 & 0 & 0 & 5 & 55.5 \\
\hline Anorexia & 42 & 34 & 89.4 & 1 & 100 & 2 & 100 & 5 & 55.5 \\
\hline Early satiety & 25 & 19 & 50 & 0 & 0 & 1 & 50 & 5 & 55.5 \\
\hline Jaundice & 1 & 1 & 2.6 & 0 & 0 & 0 & 0 & 0 & 0 \\
\hline Dysphagia & 5 & 1 & 2.6 & 0 & 0 & 0 & 0 & 4 & 44.4 \\
\hline Melena & 10 & 6 & 15.7 & 1 & 2 & 2 & 100 & 1 & 11.1 \\
\hline
\end{tabular}

\section{COMPARISON OF SYMPTOMS WITH SITE OF TUMOUR}

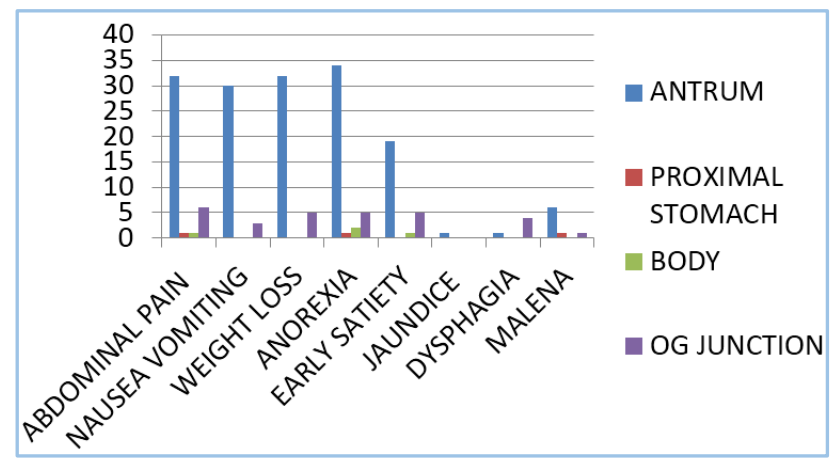

MACROSCOPY AND SYMPTOMS: TABLE 17; GRAPH 11

Bormann type 1 lesion patients experienced pain abdomen and vomiting in $100 \%$ of cases. All Bormann type II lesion patients had symptoms of nausea or vomiting, weight loss and anorexia. Type II and III lesion patients had early satiety in $75 \%$ and $50 \%$ respectively.

\begin{tabular}{|c|c|c|c|c|c|c|c|c|c|}
\hline \multirow{3}{*}{ Symptoms } & \multirow{3}{*}{ Total Cases } & \multicolumn{8}{|c|}{ Bormann Types } \\
\hline & & \multicolumn{2}{|c|}{ I (2) } & \multicolumn{2}{|c|}{ Ii (24) } & \multicolumn{2}{|c|}{ Iii (10) } & \multicolumn{2}{|c|}{ Iv (14) } \\
\hline & & Cases & $\%$ & Cases & $\%$ & Cases & $\%$ & Cases & $\%$ \\
\hline Abdominal Pain & 40 & 2 & 100 & 20 & 83.3 & 8 & 80 & 10 & 71.4 \\
\hline Nausea/Vomiting & 33 & 2 & 100 & 24 & 100 & 2 & 20 & 5 & 35.7 \\
\hline Weight Loss & 36 & 1 & 50 & 24 & 100 & 6 & 60 & 5 & 35.7 \\
\hline Anorexia & 42 & 1 & 50 & 24 & 100 & 7 & 70 & 8 & 57.1 \\
\hline Early Satiety & 25 & 1 & 50 & 18 & 75 & 5 & 50 & 1 & 7.1 \\
\hline Jaundice & 1 & 0 & 0 & 1 & 4.1 & 0 & 0 & 0 & 0 \\
\hline Dysphagia & 5 & 0 & 0 & 2 & 8.3 & 1 & 10 & 2 & 14.2 \\
\hline Melena & 10 & 1 & 50 & 4 & 16.6 & 2 & 20 & 3 & 21.4 \\
\hline
\end{tabular}

\section{COMPARISON OF SYMPTOMS WITH MACROSCOPIC APPEARANCES}




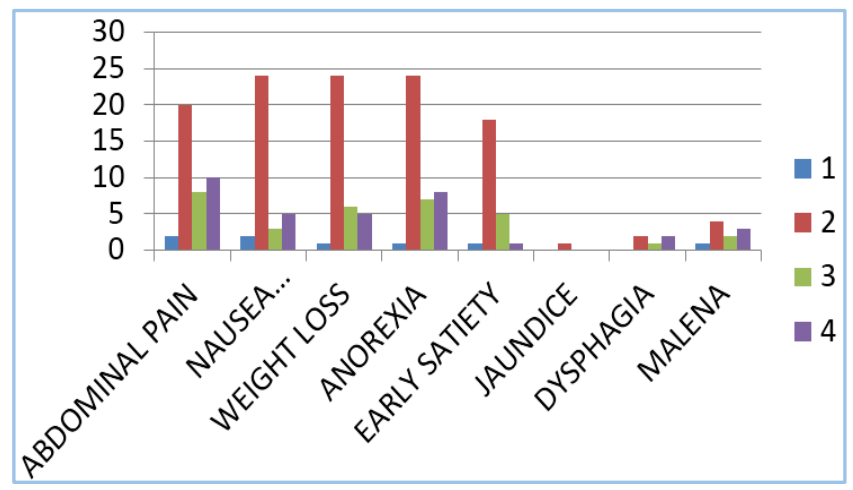

SITE AND SIGNS TABLE 18, GRAPH 12

All cases of tumours had anaemia at presentation. Tumours of the body had ascites at the time of presentation. All the cases with visible gastric peristalsis were antral growths; however, only $18.4 \%$ of antral growth has visible peristalsis.

\begin{tabular}{|c|c|c|c|c|c|c|c|c|c|}
\hline \multirow{2}{*}{ Signs } & \multirow{3}{*}{ Total Cases } & \multicolumn{9}{|c|}{ Site of Tumour } \\
\cline { 3 - 10 } & & \multicolumn{2}{|c|}{ Antrum } & \multicolumn{2}{c|}{ Proximal Stomach } & \multicolumn{2}{c|}{ Body } & \multicolumn{2}{c|}{ OG Junction } \\
\cline { 3 - 10 } & & Cases & $\mathbf{\%}$ & Cases & \% & Cases & \% & Cases & \% \\
\hline Anaemia & 35 & 28 & 73.6 & 1 & 100 & 1 & 50 & 5 & 55.5 \\
\hline Icterus & 1 & 1 & 2.6 & 0 & 0 & 0 & 0 & 0 & 0 \\
\hline Dehydration & 30 & 26 & 68.4 & 0 & 0 & 1 & 50 & 3 & 33.5 \\
\hline Ascites & 28 & 23 & 60.5 & 0 & 0 & 2 & 100 & 3 & 33.5 \\
\hline VGP & 7 & 7 & 18.4 & 0 & 0 & 0 & 0 & 0 & 0 \\
\hline Mass Abdomen & 17 & 15 & 39.4 & 0 & 0 & 2 & 100 & 0 & 0 \\
\hline
\end{tabular}

\section{ANALYSIS OF SITE OF TUMOURS WITH SIGNS}

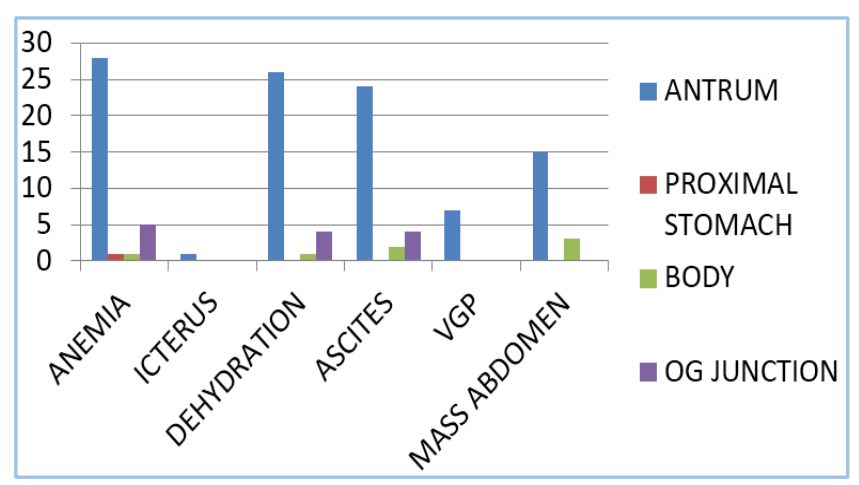

\section{MACROSCOPY AND SIGNS: TABLE 19; GRAPH 13}

Majority of type II and type III lesions presented with anaemia. Bormann type II and type IV lesions were more often associated with ascites than type I lesions. Type II and type III lesions accounted for the majority of cases of mass abdomen.

\begin{tabular}{|c|c|c|c|c|c|c|c|c|c|}
\hline Signs & $\begin{array}{c}\text { Total } \\
\text { Cases }\end{array}$ & Bormann Types & & & & & & \\
\hline & & & I (2) & II (24) & & III (10) & & IV (14) & \\
\hline & & Cases & \% & Cases & \% & Cases & \% & Cases & \% \\
\hline Anaemia & 35 & 1 & 50 & 18 & 75 & 8 & 80 & 8 & 57.1 \\
\hline Icterus & 1 & 0 & 0 & 1 & 4.1 & 0 & 0 & 0 & 0 \\
\hline Dehydration & 30 & 1 & 50 & 18 & 75 & 4 & 40 & 7 & 50 \\
\hline Ascites & 28 & 0 & 0 & 18 & 75 & 4 & 40 & 6 & 42.8 \\
\hline VGP & 7 & 0 & 0 & 5 & 20.8 & 0 & 0 & 2 & 14.2 \\
\hline Mass Abdomen & 17 & 0 & 0 & 10 & 41.6 & 6 & 60 & 1 & 7.1 \\
\hline
\end{tabular}

\section{COMPARISON OF MACROSCOPY WITH CLINICAL SIGNS}

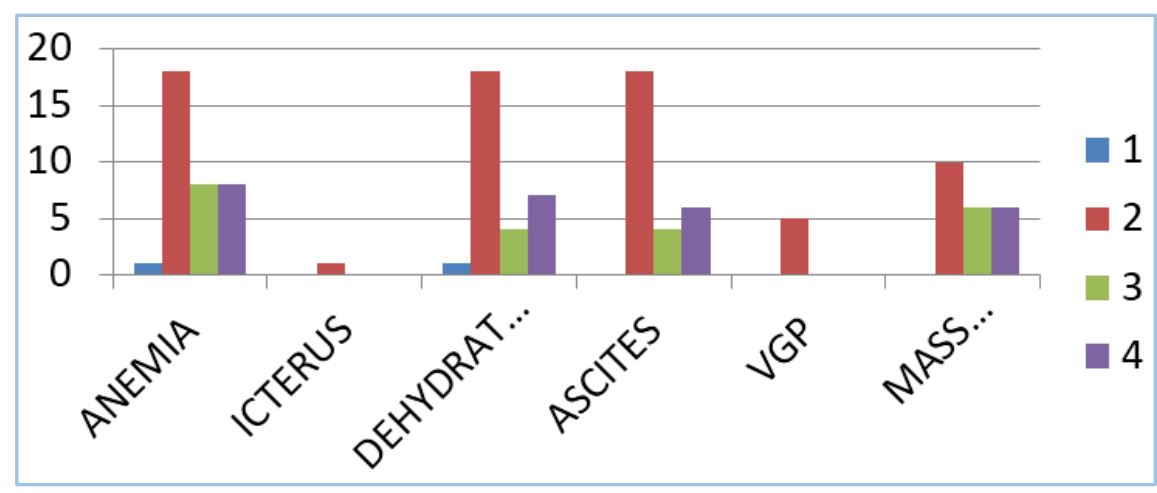


HISTOPATHOLOGY: TABLE 20, TABLE 21

Majority of cases were well-differentiated adenocarcinoma. Females had higher \% of poorly differentiated tumours.

\begin{tabular}{|c|c|c|c|c|c|c|}
\hline Histology & Present Study & & & & \\
\hline Differentiation & Total Cases & $\mathbf{\%}$ & Males & $\mathbf{\%}$ & Females & \% \\
\hline Well & 30 & 60 & 20 & 71.4 & 10 & 45.4 \\
\hline Moderately & 12 & 24 & 6 & 21.4 & 6 & 27.2 \\
\hline Poor & 8 & 16 & 2 & 7.1 & 6 & 27.2 \\
\hline Undifferentiated & 0 & 0 & 0 & 0 & 0 & 0 \\
\hline
\end{tabular}

COMPARISON OF HISTOPATHOLOGICAL TYPES AMONG SEXES

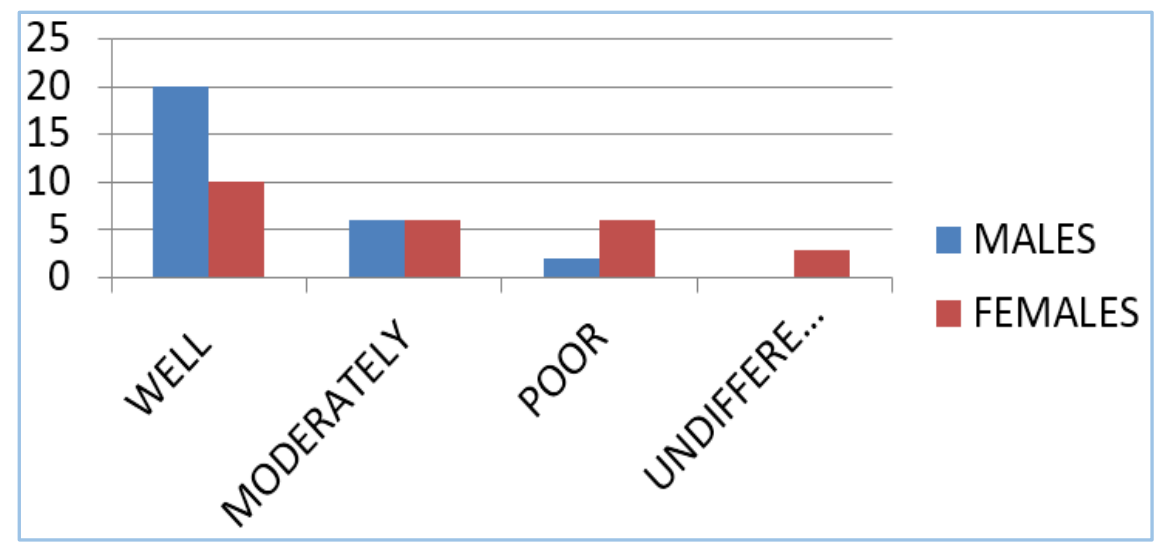

\begin{tabular}{|c|c|c|c|c|c|}
\hline Histology & $\begin{array}{c}\text { Present } \\
\text { Study }\end{array}$ & & & & \\
\hline Differentiation & Total & $\begin{array}{c}\text { Antrum } \\
38\end{array}$ & $\begin{array}{c}\text { Body } \\
1\end{array}$ & $\begin{array}{l}\text { Proximal } \\
2\end{array}$ & $\begin{array}{c}\text { OG Junc. } \\
9\end{array}$ \\
\hline Well & 30 & 30 & 0 & 0 & 0 \\
\hline Moderately & 12 & 8 & 1 & 2 & 1 \\
\hline Poor & 8 & 0 & 0 & 0 & 8 \\
\hline Undifferentiated & 0 & 0 & 0 & 0 & 0 \\
\hline
\end{tabular}

\section{COMPARISON OF HISTOLOGICAL TYPES WITH SITES}

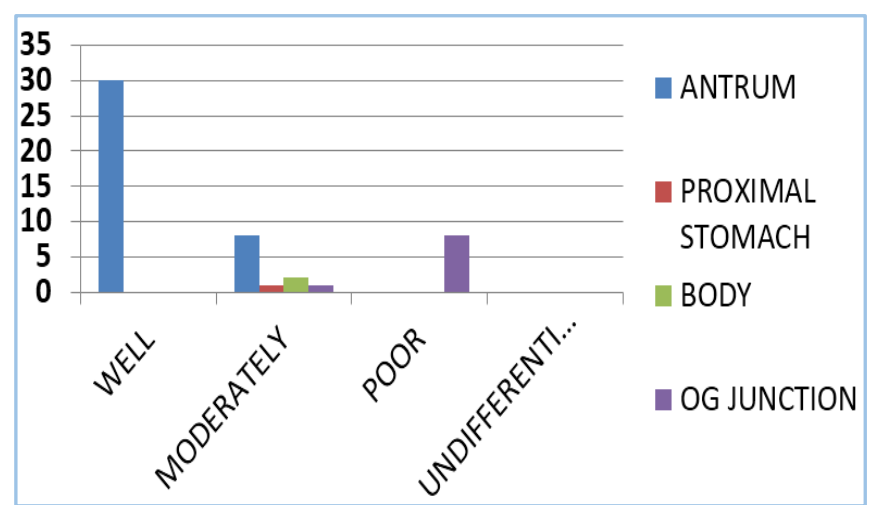

DISCUSSION
This study was undertaken to study the prevalence of gastric cancer as occurring in Adichunchanagiri Hospital, Bellur, Mandya district, which is a rural centre with a large input of cases from Mandya and its surrounding districts.

The study had certain drawbacks. The association of $\mathrm{H}$. pylori with gastric carcinoma was not studied. Since histopathological confirmation was an inclusion criterion for the study, many suspected cases were not included for lack of definite tissue diagnosis.

Although, CT abdomen is recommended for the staging of the disease, it was not performed in most of the cases due to financial constraints. Many cases were referred to the Regional Cancer Institute for the further treatment. Observations were made in this study with M:F ratio 3:1. These observations are comparable to similar studies in India.

\begin{tabular}{|c|c|c|c|c|c|c|}
\hline Sex & Gajalakshmi et al. 1995 & & Sumathi et al. 2009 & & Present Study & Cases \\
\hline & Cases & \% & Cases & \% & 28 \\
\hline Male & 287 & 73.9 & 64 & 71.9 & 56 \\
\hline Female & 101 & 26.1 & 25 & 28.1 & 22 \\
\hline \multicolumn{2}{|c|}{ Table 21: Sex Distribution among Carcinoma Stomach Patients } \\
\hline
\end{tabular}

In this study, maximum no. of cases was seen after the age of 45 yrs. In this study, the youngest patient was aged 29 and the oldest 78 . 


\begin{tabular}{|c|c|c|c|c|c|c|}
\hline Age & Gajalakshmi CK et al. 1996 & & Sen et al. 2002 & Present Study & Cases & \% \\
\hline & Cases & $\mathbf{\%}$ & Cases & 0.1 & 1 & 2 \\
\hline$<30$ & 2 & 0.5 & 0 & 0.5 & 7 & 14 \\
\hline $30-39$ & 30 & 7.7 & 7 & 2.2 & 9 & 18 \\
\hline $40-49$ & 64 & 16.5 & 1 & 7.2 & 15 & 30 \\
\hline $50-59$ & 84 & 21.6 & 20 & 19.2 & 12 & 24 \\
\hline $60-69$ & 124 & 32 & 53 & 28 & 6 & 12 \\
\hline $70-79$ & 68 & 17.5 & 77 & 43.4 & 0 & 0 \\
\hline $80+$ & 16 & 4.1 & 120 & & 0 \\
\hline
\end{tabular}

As the study was conducted in a rural hospital, majority of the cases belonged to a low socioeconomic status accounting for $75 \%$ of the cases. The scenario is similar across India, where majority of population belong to the low socioeconomic group, further contributing evidence of dietary role of carcinogens. Studies at Tamilnadu and other parts of country have shown consistent correlation between the lower socioeconomic group and higher prevalence of gastric cancer.

\begin{tabular}{|c|c|c|c|c|c|c|}
\hline $\begin{array}{c}\text { Socioeconomic } \\
\text { Status }\end{array}$ & $\begin{array}{c}\text { Gajalakshmi } \\
\text { et al. 1995 }\end{array}$ & Sumathi et al. 2009 & Present Study & Cases \\
\hline & Cases & \% & Cases & $\%$ & 40 & 80 \\
\hline Low & 301 & 77.5 & 70 & 78.6 & 10 & 20 \\
\hline Middle & 87 & 22.5 & 19 & 21.4 & 0 \\
\hline High & 0 & 0 & 0 & 0 & 0 \\
\hline
\end{tabular}

\begin{tabular}{|c|c|c|c|c|}
\hline Study & Blood Group & & & \\
\hline & A (\%) & B (\%) & $\mathbf{O}(\%)$ & AB (\%) \\
\hline $\begin{array}{l}\text { Kamlesh Guleria } \\
\text { et al., Punjab }\end{array}$ & $1(12.5)$ & $5(62.5)$ & $2(25)$ & $0(0)$ \\
\hline Jose et al., Kerala & $26(37.1)$ & $14(20)$ & $23(32.85)$ & $7(10)$ \\
\hline Present Study & $23(46)$ & $9(18)$ & $12(24)$ & $6(12)$ \\
\hline
\end{tabular}

Gastric cancer is known to be associated with several environmental risk of which diet has an important role. The association of diet has been studied in many studies and consistent results obtained all over.

The findings of this study were compared with Sumathi et al. Majority of the patients were nonveg in both the studies. The association of tobacco use and alcohol has been studied. In this study, $22(45 \%)$ of the patients reported to the use of smoking for a significant period compared to 40.5 patients in study by Sumathi et al. Betel nut chewing seen more in females was seen in $16 \%$ of the patients compared to $10.2 \%$ in the other study.

\begin{tabular}{|c|c|c|c|c|}
\hline Factors & $\begin{array}{c}\text { Sumathi } \\
\text { et al. }\end{array}$ & Present Study & \\
\hline & Cases & $\mathbf{\%}$ & Cases & $\%$ \\
\hline Mixed Diet & 89 & 100 & 45 & 90 \\
\hline Veg Diet & 0 & 0 & 5 & 10 \\
\hline Green Leafy Veg & 58 & 62.5 & 40 & 80 \\
\hline Fruits & 39 & 43.8 & 40 & 80 \\
\hline High Salt Intake & 0 & 0 & 32 & 64 \\
\hline Smoked Food & 0 & 0 & 15 & 30 \\
\hline Spicy Food & 0 & 0 & 40 & 80 \\
\hline Smoking & 36 & 40.5 & 22 & 44 \\
\hline Alcohol & 32 & 35.9 & 22 & 44 \\
\hline Betel Nut & 9 & 10.2 & 8 & 16 \\
\hline \multicolumn{7}{|r}{ Table 25: Comparison of Risk } \\
\hline
\end{tabular}

Abdominal pain was major symptom reported in 40
$(80 \%)$ of the cases compared to $56.6 \%$ in a study by Safaee et al. Weight loss was seen in $36(72 \%)$ of cases compared to 57.7 cases. These findings suggest that the patients in our setup present an early stage of the disease with both local and regional spread. The percentage of patients presenting with melena was comparable in both groups.

\begin{tabular}{|c|c|c|c|c|}
\hline Symptoms & $\begin{array}{l}\text { Safee et al. } \\
2009\end{array}$ & & $\begin{array}{c}\text { Present } \\
\text { Study }\end{array}$ & \\
\hline & Cases & $\%$ & Cases & $\%$ \\
\hline Abdominal Pain & 425 & 56.6 & 40 & 80 \\
\hline $\begin{array}{l}\text { Nausea \& } \\
\text { Vomiting }\end{array}$ & 324 & 43.2 & 33 & 66 \\
\hline Weight Loss & 434 & 57.7 & 36 & 72 \\
\hline Anorexia & - & - & 42 & 84 \\
\hline Early Satiety & 263 & 31.5 & 25 & 50 \\
\hline Jaundice & - & - & 1 & 2 \\
\hline Dysphagia & 263 & 31.5 & 5 & 10 \\
\hline Melena & 144 & 19.1 & 10 & 20 \\
\hline
\end{tabular}

The west has noted a paradigm shift in site of gastric cancer tumours with a steady increase in tumours of the cardium and proximal tumours and a decline in distal tumours. In this study, distal tumours continued to be the most common site of affliction with $38(76 \%)$ cases $(18 \%)$ of proximal tumours. Cherian et al. 8 studying 16 years' trend cancer at Chennai also had similar findings. 


\begin{tabular}{|c|c|c|c|c|}
\hline Subsite & Cherian et al. & & Present Study & \\
\hline & Cases & $\%$ & Cases & $\%$ \\
\hline OG Junction & 65 & 3.78 & 9 & 18 \\
\hline $\begin{array}{c}\text { Proximal } \\
\text { Stomach }\end{array}$ & 97 & 5.64 & 1 & 2 \\
\hline Body & 400 & 23.27 & 2 & 4 \\
\hline Antrum & 1157 & 67.31 & 38 & 76 \\
\hline \multicolumn{5}{|c|}{ Table 27: Subsite Specific Trends in Carcinoma Stomach } \\
\hline
\end{tabular}

In this study, majority of the tumours were well differentiated. Moderately and poorly differentiated were equally differentiated. In this study by Safee et al., poorly differentiated tumours were more common.

\begin{tabular}{|c|c|c|c|c|}
\hline Histology & Safee et al. & & $\begin{array}{c}\text { Present } \\
\text { Study }\end{array}$ & \\
\hline Differentiation & Cases & $\%$ & Cases & $\%$ \\
\hline Well & 113 & 23 & 30 & 60 \\
\hline Moderately & 142 & 30.1 & 12 & 24 \\
\hline Poor & 203 & 43 & 8 & 16 \\
\hline Undifferentiated & 14 & 3 & 0 & 0 \\
\hline \multicolumn{4}{|r|}{ Table 28: Comparison of Histology } \\
according to Broders' Classification \\
\hline
\end{tabular}

\section{CONCLUSION}

This study was undertaken to study the prevalence of gastric cancer as occurring in Adichunchanagiri Hospital, Mandya, which is a rural hospital with a large input of cases from Mandya and its surrounding districts. In this study, gastric cancer was more prevalent in males. Majority of the patients belonged to the lower socioeconomic strata and had association of risk factor. Blood Group A was the prevalent blood group.

The disease was more prevalent in patients above age of 45 with the oldest being 78 .

Majority presented in the advanced stage of the disease, although there were few cases which presented in the early gastric carcinoma stage.

The pylorus remained the most common site of affliction in contrast to western countries, which have showed a consistent shift towards proximal tumours. The major percentage of the tumours was well differentiated. The finding of this study are comparable to other similar studies in India and proximal tumours continue to be the major subtype in this part of the world and association of risk factor increase the likelihood of an individual developing gastric cancer.

\section{SUMMARY}

Gastric cancer is a disease of the older age group.

The association of risk factor is well known and consistent and hints at the primordial prevention of the disease. Distal tumours continue to be the major subtype in this study. Successful preventive strategies have to be developed, a multischolastic approach should combine population screening with biological techniques that are being developed.

\section{REFERENCES}

1. Fukayama M, Hayashi Y, Iwasaki Y, et al. Epstein-barr virus associated gastric carcinoma and epstein-barr virus infection of the stomach. Lab Invest 1994;71(1):73-81.

2. Correa P. Carcinoma of the stomach. proceedings of the Nutrition society 1985;44(1):111-2.

3. Morson BC, Sobin LH, Grundmann E, et al. Precancerous conditions and epithelial dysplasia in the stomach. J Clin Pathol 1980;33(8):711-21.

4. Samuel B Ho. Tumours of the stomach \& small intestine, current diagnosis \& treatment in gastyroenterology, Ch 24, Scott L Friedman, Kenneth R Mcquaid, James H Grendell. By McGraw-Hill/Appleton \& Lange 2002; $2^{\text {nd }}$ Ed.

5. John NP. Stomach \& duodenum, Ch 50, Bailey and Love's short practice of surgery Norman S Williams, Christoper Jk Bulstrode, Ronan O'Connell P, Edward Arnold Pub. Ltd, 2008;25th edition:1067-74.

6. Japanese gastric cancer association. Japanese classification of gastric carcinoma, 2nd edition. Gastric cancer 1998;1:10.

7. Murray F Brenman. Gastric adenocarcinoma, Maingot's Abdominal Operations, Michael J Zinner, Stanley W Ashley Ch 14, 2007;11 ed:p 417-7th.

8. David M Roder. The epidemiology of gastric cancer. Gastric Cancer 2002;5(1):5-11. 